\title{
UPAYA MENINGKATKAN KEMAMPUAN KINESTETIK-JASMANI MELALUI PERMAINAN SEPAK BOLA ANAK USIA 5-6 TAHUN DI PAUD SEGAR JAYA DESA SEGAYAM
}

\author{
Eta Puspita1, Dr. Hj. Taty Fauzi M.Pd², \\ Email : Etapuspita28051997@gmail.com¹, tatyfauzi@yahoo.co.id²,
}

\begin{abstract}
Abstrak : Penelitian Tindakan Kelas (PTK) berjudul "Upaya Meningkatkan Kemampuan Kinestetik Jasmani Melalui Permainan Sepak Bola Anak Usia 5-6 Tahun Di PAUD Segar Jaya Desa Segayam Tahun 2019'”. Penelitian ini dilatarbelakangi oleh rendahnya kemampuan kinestetik jasmani anak. Jenis Penelitian ini adalah Penelitian PTK yang dilaksanakan II Siklus. Dalam I Siklus 5 kali pertemuan maka jika II Siklus berjumlah 10 kali pertemuan. Subjek dalam penelitian ini adalah 14 orang anak yang terdiri dari 9 anak laki-laki dan 5 anak perempuan. Tehnik pengumpulan data yang digunakan dalam penelitian ini menggunakan observasi dan dokumentasi. Instrument penelitian yaitu observasi (Cheklis). Indikator keberhasilan yang ditetapkan jika minimal $80 \%$ dari 14 anak yang memperoleh nilai tuntas. Sebelum melakukan tindakan siklus I dan siklus II peneliti melakukan pertemuan pra tindakan. Pada pertemuan pra tindakan nilai ketuntasan anak baru mencapai 14,3, setelah dilakukan tindakan pada siklus I meningkat menjadi 42,9\% dilanjutkan pada siklus II nilai ketuntasan anak meningkat menjadi 85,7\%. Dari perolehan presentase pada siklus II yang telah mencapai $80 \%$ sehingga dapat disimpulkan bahwa kemampuan kinestetik jasmani anak PAUD Segar Jaya Kelompok B2 dapat meningkat melalui permaianan sepak bola.
\end{abstract}

Kata Kunci : Kemampuan Kinestetik Jasmani, Permainan Sepak Bola

\section{PENDAHULUAN}

Anak usia dini merupakan kelompok usia yang berbeda dalam proses perkembangan unik, karena perkembanganya (tumbuh dan berkembang) terjadi bersama golden age (masa peka). Golden age merupakan masa yang sangat tepat untuk menggali segala potensi kemampuan anak baik kemampuan jasmani dan rohani. Setiap kemampuan yang dimiliki anak akan dapat mengantarkan anak mencapai kesuksesan dan pertumbuhan dengan baik. Usia 0 sampai 6 tahun merupakan masa keemasan sekaligus masa kritis dalam tahapan kehidupan manusia yang akan menentukan perkembangan anak.
Anak-anak pada masa ini memerlukan berbagai layanan dan bantuan dari kebutuhan jasmani dan rohani, dimana bentuk layanan tersebut diarahkan untuk memfasilitasi pertumbuhan sebagai peletakan dasar yang tepat bagi pertumbuhan dan perkembangan anak seutuhnya, sehingga anak dapat tumbuh kembang optimal sesuai nilai norma serta harapan masyarakat.

Pendidik atau guru perlu memfasilitasi dan mempertahankan setiap kemampuan yang dimiliki anak agar bertahan sampai tumbuh dewasa, dengan memberikan faktor lingkungan dan stimulasi yang baik untuk merangsang dan mengoptimalkan kemampuan anak salah satunya adalah kemampuan kinestetik- 
jasmani, kemampuan dalam menggunakan anggota tubuh untuk melakukan gerakan.

Pada usia 2 atau 3 tahun kemampuan kinestetik-jasmani anak mulai tumbuh sejalan dengan kemampuan kinestetikjasmani yang perlu di optimalkan sejak dini ditemukan strategi yang dapat dilakukan untuk meningkatkan kemampuan kinestetik-jasmani anak ialah melalui kegiatan permainan sepak bola. Permainan Sepak Bola adalah permainan yang dimainkan oleh dua kelompok yang disebut tim setiap tim memiliki kotak yang dilengkapi dengan jaring, mereka saling berhadapan dengan tujuan untuk menendang memasukan bola kedalam kotak dengan jaring di masing-masing lawan

Berdasarkan pengamatan peneliti ketika melakukan penelitian pada PAUD Segar Jaya usia 5-6 Tahun di Desa Segayam terdiri dari 14 orang anak dari 14 orang anak 10 anak diantaranya kemampuan kinestetik-jasmaninya belum berkembang dengan optimal.

Hal ini terlihat saat melakukan permainan di luar ruangan masih banyak anak belum mampu menangkap bola, menendang bola dengan terarah, dan masih banyak anak tidak mau bergerak dalam permainan hal ini menunjukkan kemampuan-kinestetik jasmani anak belum berkembang dengan baik dan masih perlu memfasilitasi dan meningkatkan kemampuan kinestetik-jasmani anak dengan memberikan faktor lingkungan dan stimulasi yang lebih baik untuk menambah minat anak dalam melakukan permainan diluar ruangan agar kemampuan kinestetik jasmani anak dapat meningkat dengan optimal. Belum optimalnya kemampuan kinestetik jasmani anak dikrnakam kegiatan kinestetik jasmani jarang diterapkan membuat kemampuan kinestetik jasmani anak belum optimal dengan baik.

Penelitian yang dilakukan oleh Rizki (2015) dengan judul "Mengembangkan Kemampuan Motorik Kasar Melalui Bermain Sepak Bola Pada Anak Kelompok A TK Mayitoh Al-Amin" menyatakan bahwa $80 \%$ pada siklus II mengalami peningkatan setelah menerapkan permaianan sepak bola.

Berdasarkan latar belakang serta melihat permasalahan yang ada maka peneliti akan melakukan penelitian dengan judul Upaya Meningkatkan Kemampuan Kinestetik Jasmani Melalui Permainan Sepak Bola Anak Usia 5-6 Tahun Di Paud Segar Jaya Desa Segayam ". Dengan harapan agar tingkat kemampuan kinestetik-jasmani Anak PAUD Segar Jaya dapat meningkat dengan optimal. 


\section{TINJAUAN PUSTAKA}

1. Kemampuan Kinestetik Jasmani

a. Kemampuan

Menurut Sudiro (2018:3) Menjelaskan kemampuan adalah sebuah penilaian saat ini atas apa yang bisa dilakukan seorang.

Menurut Poerwadarmita dalam Suherman (2017:2) 'mampu' bearti kuasa, sanggup melakukan sesuatu sedangkan 'kemampuan' berarti kesanggupan untuk melakukan sesuatu.

Selanjutnya Gipson dalam Budio (2012:127) Menjelaskan kemampuan adalah menunjukan potensi orang untuk melaksanakan tugas atau pekerjaan. Jadi, kemampuan adalah pondasi dalam perkembangan anak yang perlu digali sejak dini kemampuan dalam melaksanakan tugas atau pekerjaan.

Menurut tiga pendapat diatas diatas dapat disimpulkan bahwa kemampuan adalah sebuah penilaian atas apa yang bisa dilakukan seorang sanggup melakukan sesuatu, dan potensi seorang untuk melaksanakan tugas atau pekerjaan.

b. Kecerdasan Kinestetik

Menurut Gardner dalam Umama (2016:15) Menjelaskan Kecerdasan kinestetik (Gerak Tubuh) adalah Kemampuan seseorang untuk menuangkan perasaanya dalam gerakan tubuh.

Menurut Gnantza dalam Madyawati (2017:22) Menjelaskan Kecerdasan kinestetik adalah suatu kecerdasan ketika saat menggunakanya seseorang mampu atau terampil menggunakan anggota tubuhnya untuk melakukan gerakan, seperti berlari, menari, membangun sesuatu, melakukan kegiatan seni,dan hasta karya.

Selanjutnya menurut Amstrong dalam Sujiono (2013:59) Menjelaskan kecerdasan kinestetik adalah suatu kecerdasan dimana saat menggunakannya seseorang mampu atau terampil menggunakan anggota tubuhnya untuk melakukan gerakan seperti, berlari, membangun sesuatu, melakukan kegiatan seni dan hasta karya.

Menurut tiga pendapat tersebut dapat disimpulkan bahwa kecerdasan kinestetik adalah kemampuan dalam melakukan gerakan-gerakan tubuh dan kemampuan seseorang untuk menuangkan perasaanya dalam gerakan tubuh seperti berlari, menari, membangun sesuatu, melakukan kegiatan seni,dan hasta karya

c. Jasmani

Menurut Nataniel dalam Muhajir (2015:105) Menjelaskan bahwa jasmani adalah tubuh manusia. Sedangkan Hamka dalam Rochim (2017:72) Menjelaskan bahwa jasmani (jism) manusia adalah tempat dimana jiwa (al-qalb) berada. Menurut pendapat diatas dapat 
disimpulkan bahwa jasmani adalah tubuh manusia tempat dimana jiwa berada.

Dari beberapa definisi kemampuan, kecerdasan kinestetik dan jasmani yang dijelaskan diatas dapat disimpulkan bahwa kemampuan kinestetik-jasmani adalah suatu kemampuan dalam melakukan gerakan tubuh, kemampuan seseorang untuk menuangkan perasaanya dalam gerakan dan terampil menggunakan anggota tubuhnya untuk melakukan gerakan, seperti berlari, menari, membangun sesuatu, melakukan kegiatan seni,dan hasta karya

1. Permainan Sepak Bola

a. Permainan

Menurut Santrock dalam Kurniati (2016:1) Menjelaskan permainan adalah kegiatan yang menyenangkan yang dilaksanakan untuk kepentingan kegiatan itu sendiri. Jadi, permainan adalah kegiatan yang menyenangkan kegiatan yang dirancang dengan maksud meningkatkan beberapa kemampuan.

Menurut Semiawan dalam Murtadlo (2016:340) Menjelaskan Permainan adalah media bagi anak untuk menjelajahi dunianya dari yang tidak ia kenali sampai pada ia ketahui dan dari yang tidak dapat di perbarui sampai ia dapat perbarui hingga anak dapat melakukannya.

Selanjutnya Sawyer dalam Yuliani (2013:145) Menjelaskan permainan secara langsung mempengaruhi seluruh area perkembangan anak dengan memberikan kesempatan bagi anak untuk belajar tentang dirinya, orang lain dan lingkungannya.

Menurut tiga pendapat tersebut dapat disimpulkan bahwa permainan adalah kegiatan yang menyenangkan dan media bagi anak untuk menjelajahi dunianya dari yang ia tidak kenali sampai pada ia ketahui dari ia tidak dapat perbarui sampai ia dapat perbarui, secara langsung dapat mempengarui seluruh area perkembangan anak dengan memberikan kesempatan anak belajar dirinya, orang lain dan lingkungan sekitarnya.

b. Sepak Bola

Menurut Mikanda (2014:99) Menjelaskan Sepak bola merupakan salah satu cabang olahraga yang paling banyak diminati penduduk dunia, tidak terkecuali di Indonesia, Cabang olahraga ini dimainkan oleh 11 orang pemain dan dilakukan di sebuah lapangan berumput yang sangat luas.

Menurut Eci (2017:13) Menjelaskan Sepak bola adalah olahraga menendang bola yang dimainkan oleh dua tim, setiap tim terdiri dari sebelas pemain. Jadi, sepak bola adalah cabang olahraga yang menggunakan bola yang umumnya terbuat dari bahan kulit yang dimainkan oleh dua tim setiap tim terdiri dari sebelas orang. 
Menurut Witono (2017:6) Menjelaskan Sepak bola adalah salah satu cabang olahraga yang dimainkan diluar ruangan, olahraga ini dimainkan di atas sebuah kawasan yang lapang oleh dua kelompok yang disebut tim setiap tim memiliki kotak yang dilengkapi dengan jaring mereka saling berhadapan dengan tujuan untuk memasukan bola kedalam kotak dengan jaring di masing-masing lawan.

Menurut tiga pendapat diatas dapat disimpulkan bahwa sepak bola adalah cabang olahraga paling banyak diminati penduduk dunia permainan yang dimainkan oleh dua kelompok yang disebut tim setiap tim terdiri dari 11 orang dan memiliki kotak yang dilengkapi dengan jaring mereka saling berhadapan dengan tujuan untuk menendang memasukan bola kedalam kotak dengan jaring di masing-masing lawan.

Dari beberapa pengertian permainan dan sepak bola yang dijelaskan di atas dapat disimpulkan bahwa permainan sepak bola adalah kegiatan yang menyenangkan paling banyak diminati penduduk dunia permainan yang dimainkan oleh dua kelompok yang disebut tim setiap tim terdiri dari 11 orang dan memiliki kotak yang dilengkapi dengan jaring mereka saling berhadapan dengan tujuan untuk menendang memasukan bola kedalam kotak dengan jaring di masing-masing lawan.

\section{METODELOGI PENELITIAN}

Metode Penelitian adalah cara yang dilakukan dalam mengumpulkan data penelitiannya. Metode yang digunakan dalam penelitian ini adalah Penelitian Tindakan Kelas (PTK). Penelitian Tindakan Kelas yang umum disingkat dengan PTK dalam bahasa inggris disebut Classroom Action Research disingkat CAR adalah penelitian tindakan yang dilakukan oleh guru dengan tujuan memperbaiki mutu praktik pembelajaran dikelas. Dalam PTK guru memberikan tindakan kepada siswa tindakan tersebut merupakan kegiatan yang sengaja dirancang untuk dilakukan oleh siswa dengan tujuan tertentu. Subjek penelitian ini adalah Anak PAUD Segar Jaya Usia 56 Tahun Kelompok B Desa Segayam yang berjumlah 14 Anak. Yang dilaksanakan di PAUD Segar Jaya Desa Segayam. Penelitian ini dilaksanakan pada bulan Juli s.d Agustus 2019

\section{HASIL PENELITIAN}

Hasil penelitian ini menunjukan adanya peningkatan kemampuan kinestetik jasmani melalui permainan sepak bola anak usia 5-6 tahun di PAUD Segar Jaya Desa Segayam dengan materi pada tema anggota tubuh pada pra tindakan, siklus I dan siklus II 
Dari hasil pengamatan pada pra siklus, siklusn I dan siklus II kegiatan kemampuan kinestetik jasmani anak diperjelas melalui grafik berikut :

\section{Gambar 1}

Grapik Kemampuan Kinestetik Jasmani Pra Tindakan

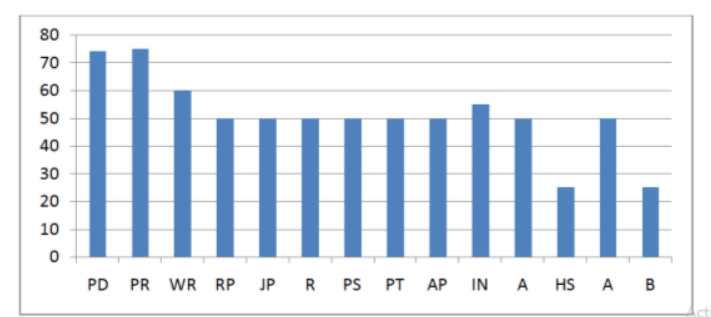

Dari gambar 1 hasil observasi kemampuan kinestetik jasmani pra siklus diatas dapat diperjelas melalui tabel 1 dibawah ini

\section{Tabel 1}

Rekapitulasi Data Kemampuan Kinestetik Jasmani Pra Tindakan

\begin{tabular}{|c|l|c|c|}
\hline No & Kriteria & $\begin{array}{c}\text { Jumlah } \\
\text { Anak }\end{array}$ & Presentase \\
\hline 1 & Tuntas & 2 & 14,3 \\
\hline 2 & $\begin{array}{l}\text { Tidak } \\
\text { Tuntas }\end{array}$ & 12 & 85,7 \\
\hline
\end{tabular}

Dari tabel rekapitulasi data kegiatan

pada pra siklus diatas dapat diperoleh

keterangan bahwa terdapat 2 anak yang memiliki karakteria tuntas dengan presentase $14,3 \%$, hal ini terlihat saat anak melakukan permaianan sepak bola anak mampu menuangkan perasaannya dalam gerakan tubuh, anak terampil melakukan gerakan-gerakan menggunakan anggota tubuh saat melakukan permaianan sepak bola, dan anak mampu berlari saat melakukan permainan sepak bola. Sedangkan kreteria tidak tuntas terdapat 12 anak dengan presentase $85,7 \%$, kedua belas anak tersebut belum mampu menuangkan perasaannya dalam gerakan tubuh saat melakukan permaianan sepak bola, anak belum mampu melakukan gerakan-gerakan menggunakan anggota tubuh saat melakukan permaianan sepak bola, dan anak belum mampu berlari saat melakukan permainan sepak bola.

Dari hasil pengamatan pada pra tindakan dari tabel 2 diatas observasi kegiatan kemampuan kinestetik jasmani anak akan diperjelas melalui grafik berikut ini :

\section{Gambar 2}

Grafik Kemampuan Kinestetik Jasmani Pra Tindakan

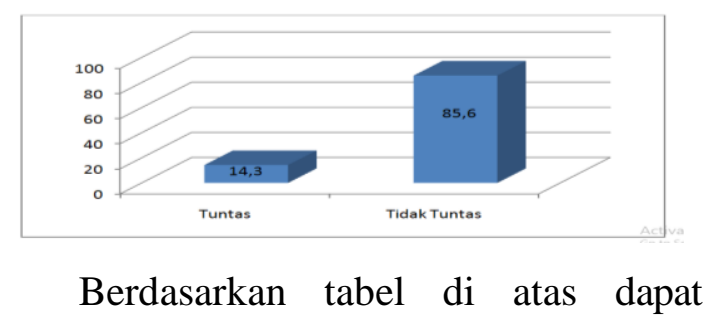

disimpulkan bahwa kemampuan kinestetik jasmani saat pra siklus atau sebelum dilakukan tindakan kelas yaitu anak berada pada persentase $14,3 \%$ belum berkembang (BB) sehingga belum mencapai kriteria keberhasilan yang telah ditentukan. Guru sebagai peneliti berusaha mencari solusi dan melakukan perbaikan saat kegiatan dalam meningkatkan kemampuan 
kinestetik jasmani anak usia 5-6 tahun. Hal ini dilakukan supaya kemampuan kinestetik jasmani anak meningkat.

Observasi

Observasi dilaksanakan selama proses praktik dilapangan dengan menggunakan lembar observasi yang telah dibuat. Observasi dilakukan untuk melihat secara langsung bagaiamana meningkatkan kemampuan kinestetik jasmani anak usia 5-6 tahun di PAUD Segar Jaya Desa Segayam Kecamatan Pemulutan Selatan.

Dari hasil pengamatan pada siklus I. observasi kegiatan kemampuan kinestetik jasmani anak usia 5-6 tahun siklus I diperjelas melalui grafik presentase berikut

\section{Gambar 3}

\section{Grafik Kemampuan Kinestetik Jasmani} Siklus I

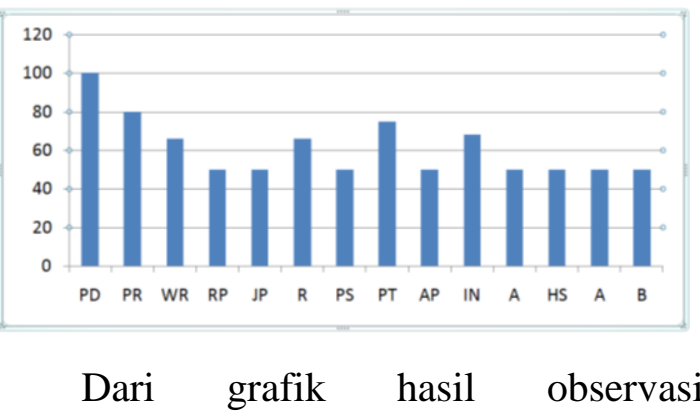

kemampuan kinestetik jasmani anak usia 5-6 tahun siklus I di atas dapat diperjelas melalui tabel 4.4 di bawah ini.
Tabel 2

Rekapitulasi data kemampuan kinestetik jasmani anak usia 5-6 tahun siklus I

\begin{tabular}{|c|l|c|c|}
\hline $\begin{array}{c}\text { N } \\
\text { o }\end{array}$ & Kriteria & $\begin{array}{c}\text { Jumlah } \\
\text { Anak }\end{array}$ & Presentase \\
\hline 1 & Tuntas & 6 & 42,9 \\
\hline 2 & $\begin{array}{l}\text { Tidak } \\
\text { Tuntas }\end{array}$ & 8 & 57,1 \\
\hline
\end{tabular}

Dari tabel rekapitulasi data kegiatan anak siklus I di atas dapat diperoleh ketarangan bahwa anak yang memiliki kriteria Tuntas ada 6 anak dengan presentase $42,9 \%$, hal ini terlihat saat anak melakukan permaianan sepak bola anak mampu menuangkan perasaannya dalam gerakan tubuh, anak terampil melakukan gerakan-gerakan menggunakan anggota tubuh saat melakukan permaianan sepak bola, dan anak mampu berlari saat melakukan permainan sepak bola. Sedangkan kriteria tidak tuntas ada 8 anak dengan presetase $57,1 \%$, kedelapan anak tersebut belum mampu menuangkan perasaannya dalam gerakan tubuh saat melakukan permaianan sepak bola, anak belum mampu melakukan gerakan-gerakan menggunakan anggota tubuh saat melakukan permaianan sepak bola, dan anak belum mampu berlari saat melakukan permainan sepak bola. 
Dari hasil pengamatan pada siklus I, dari tabel 4.4 di atas observasi kemampuan kinestetik jasmani anak usia 5-6 tahun siklus I diperjelas melalui grafik presentase berikut :

\section{Gambar 4}

\section{Grafik Kemampuan Kinestetik Jasmani} Siklus I

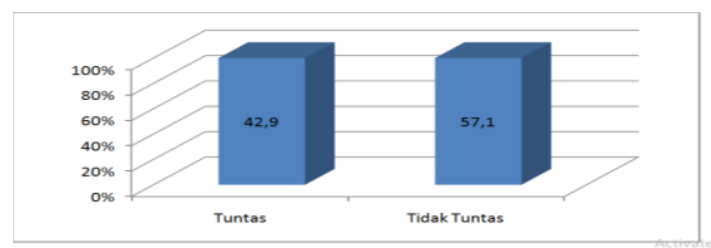

Dikeahui bahwa hasil tindakan Siklus I meningkat menjadi persentase $42,9 \%$ dengan kriteria mulai berkembang ( $\mathrm{MB}$ ). sehingga belum mencapai kriteria keberhasilan yang telah ditentukan. Guru sebagai peneliti berusaha mencari solusi dan melakukan perbaikan saat kegiatan dalam meningkatkan kemampuan kinestetik jasmani anak usia 5-6 tahun. Hal ini dilakukan supaya kemampuan kinestetik jasmani anak meningkat dengan optimal.

Tindakan penelitian pada Siklus I masih perlu perbaikan, diharapkan pada siklus II dapat lebih baik dalam meningkatkan kemampuan kinestetik jasmani anak usia 5-6 tahun. Perlu adanya rencana langkah-langkah perbaikan yangn akan digunakan pada siklus II.

Dari hasil pengamatan pada siklus II. Observasi kegiatan kemampuan kinestetik jasmani anak usia 5-6 tahun siklus II diperjelas melalui grafik presentase berikut

\section{Gambar 5}

\section{Grafik kemampuan kinestetik jasmani}

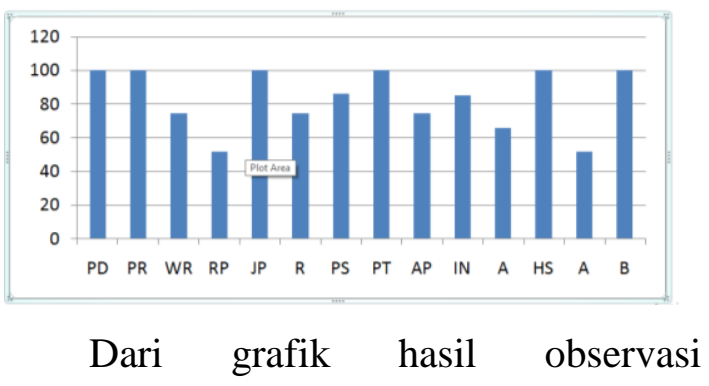

kemampuan kinestetik jasmani anak usia 5-6 tahun siklus II di atas dapat diperjelas melalui tabel 6 di bawah ini.

Tabel 3

Rekapitulasi data kemampuan kinestetik jasmani anak usia 5-6 tahun siklus II

\begin{tabular}{|c|l|c|c|}
\hline $\begin{array}{c}\text { N } \\
\text { o }\end{array}$ & Kriteria & $\begin{array}{c}\text { Jumlah } \\
\text { Anak }\end{array}$ & Presentase \\
\hline 1 & Tuntas & 12 & 85,7 \\
\hline 2 & $\begin{array}{l}\text { Tidak } \\
\text { Tuntas }\end{array}$ & 2 & 14,3 \\
\hline
\end{tabular}

Dari tabel rekapitulasi data kegiatan anak siklus II di atas dapat diperoleh ketarangan bahwa anak yang memiliki kriteria Tuntas ada 12 anak dengan presentase $85,7 \%$, hal ini terlihat saat anak melakukan permaianan sepak bola anak mampu menuangkan perasaannya dalam gerakan tubuh, anak terampil melakukan gerakan-gerakan menggunakan anggota tubuh saat melakukan permaianan sepak bola, dan anak mampu berlari saat melakukan permainan sepak bola. 
Sedangkan kriteria tidak tuntas ada 2 anak dengan presetase 14,3\%, kedua anak tersebut belum mampu menuangkan perasaannya dalam gerakan tubuh saat melakukan permaianan sepak bola, anak belum mampu melakukan gerakan-gerakan menggunakan anggota tubuh saat melakukan permaianan sepak bola, dan anak belum mampu berlari saat melakukan permainan sepak bola.

Dari hasil pengamatan pada siklus II, dari tabel di atas observasi kemampuan kinestetik jasmani anak usia 5-6 tahun siklus II diperjelas melalui grafik presentase berikut :

\section{Gambar 6}

\section{Grafik Kemampuan Kinestetik Jasmani} Siklus II

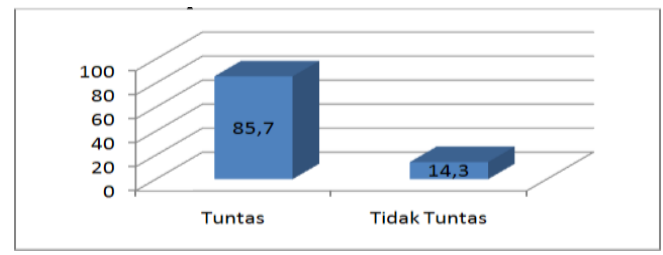

Dikeahui bahwa hasil tindakan

Siklus II anak berada pada persentase 85,7 sehingga meningkat pada kriteria berkembang Sangat Baik (BSB). Oleh karena itu peneliti menganggap hasil penelitian siklus II telah sesuai dengan hipotesis.

Hasil observasi padaSiklus II menunjukkan peningkatan kemampuan kinestetik jasmani anak usia 5-6 tahun kelompok B2 telah mencapai indikator keberhasilan yaitu sebesar $85 \% .7$

\section{PEMBAHASAN}

Berdsarkan hasil pengamatan setelah pemberian tindakan, terdapat perubahan terhadap kemampuan Kinestetik Jasmani anak kelompok B2 (usia 5-6 tahun) di PAUD Segar Jaya Desa Segayam Kecamatan Pemulutan Selatan. Perubahan ini terjadi setelah peneliti melakukan penelitian dengan peragaan langsung dan mengurangi jarak tempuh kejauhan gawang pada saat praktik guna meningkatkan kemampuan kinestetik jasmani anak usia 5-6 tahun PAUD Segar Jaya Desa Segayam Kecamatan Pemulutan Selatan. Peningkatan tersebut terlihat sejak sebelum pemberian tindakan (prasiklus) sampai dengan siklus kedua. Pada tahap pra siklus, terdapat 2 anak yang memiliki karakteria tuntas dengan presentase 14,3\% dan kreteria tidak tuntas terdapat 12 anak dengan presentase $85,7 \%$.

Setelah diberikan tindakan pada siklus pertama dengan melakukan pembelajaran dan praktik dilapangan pada anak kelompok B2 PAUD Segar Jaya Desa Segayam Kecamatan Pemulutan Selatan. Pada siklus pertama terdapat 6 anak dengan presentase $42,9 \%$ dan kriteria tidak tuntas ada 8 anak dengan presetase $57,1 \%$. Selanjutnya, pada siklus kedua, terdapat Tuntas ada 12 anak dengan 
presentase $85,7 \%$ dan kriteria tidak tuntas ada 2 anak dengan presetase $14,3 \%$.

Berikut adalah hasil penelitian kemampuan meningkatkan kinestetik jasmani kelompok B2 PAUD Segar Jaya Desa Segayam Kecamatan Pemulutan Selatan disajikan dalam tabel:

Tabel 4

Rekapitulasi Perbandingan Kemampuan Meningkatkan Kinestetik Jasmani, Siklus I dan Siklus II.

\begin{tabular}{|c|c|c|c|}
\hline No & Kriteria & $\begin{array}{c}\text { Siklus } \\
\text { I }\end{array}$ & $\begin{array}{c}\text { Siklus } \\
\text { II }\end{array}$ \\
\hline 1 & Tuntas & 42,9 & 85,7 \\
\hline 2 & $\begin{array}{l}\text { Belum } \\
\text { Tuntas }\end{array}$ & 57,1 & 14,3 \\
\hline \multicolumn{2}{|c|}{ Total } & $100 \%$ & $100 \%$ \\
\hline
\end{tabular}

Dari data di atas diketahui bahwa upaya dalam meningkatkan kemampuan kinestetik jasmanai anak pada Siklus I yang tuntas berada pada presentase $42,9 \%$ dan kriteria belum tuntas sebesar 57,1\% Dan siklus II anak yang memiliki kriteria tuntas sebesar 85,7 \% dan karakteria belum tuntas sebesar 14,3\% . Data pada tabel 4.6 persentase, siklus I dan siklus II. di atas daat dijelaskan melalui grafik perbandingan antar siklus di bawah ini

\section{Gambar 7}

Grafik perbandingan antara siklus I \& siklus II

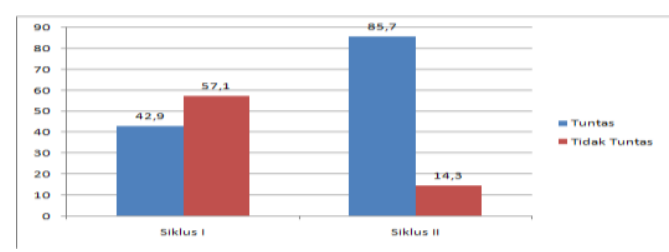

Dari grafik perbandingan antara siklus I dan siklus II mengalami peningkatan. pada Siklus I yang tuntas berada pada presentase 42,9 \% dan Dan siklus II anak yang memiliki kriteria tuntas sebesar $85,7 \%$.

Sebelumnya, Menurut Poerwadarmita dalam Suherman (2017:2) 'mampu' bearti kuasa, sanggup melakukan sesuatu sedangkan 'kemampuan' berarti kesanggupan untuk melakukan sesuatu. Selanjutnya Menurut Gipson dalam Budio (2012:127) Menjelaskan kemampuan adalah menunjukan potensi orang untuk melaksanakan tugas atau pekerjaan.

Menurut Gardner dalam Umama (2016:15) Menjelaskan Kecerdasan kinestetik (Gerak Tubuh) adalah Kemampuan seseorang untuk menuangkan perasaanya dalam gerakan tubuh. Selanjutnya

Menurut Gnantza dalam Madyawati (2017:22) Menjelaskan Kecerdasan kinestetik adalah suatu kecerdasan ketika saat menggunakanya seseorang mampu atau terampil menggunakan anggota 
tubuhnya untuk melakukan gerakan, seperti berlari, menari, membangun sesuatu, melakukan kegiatan seni,dan hasta karya.

Selain itu Menurut Amstrong dalam Sujiono (2013:59) Menjelaskan kecerdasan kinestetik adalah suatu kecerdasan dimana saat menggunakannya seseorang mampu atau terampil menggunakan anggota tubuhnya untuk melakukan gerakan seperti, berlari, membangun sesuatu, melakukan kegiatan seni dan hasta karya.

Menurut Nataniel dalam Muhajir (2015:105) Menjelaskan bahwa jasmani adalah tubuh manusia. Selanjutnya Menurut Hamka dalam Rochim (2017:72) Menjelaskan bahwa jasmani (jism) manusia adalah tempat dimana jiwa (alqalb) berada.

Dari beberapa pendapat diatas dapat disimpulkan bahwa kemampuan kinestetik jasmani adalah kemampuan dalam melakukan gerakan tubuh, kemampuan seseorang untuk menuangkan perasaanya dalam gerakan dan terampil menggunakan anggota tubuhnya untuk melakukan gerakan, seperti berlari, menari, membangun sesuatu, melakukan kegiatan seni,dan hasta karya.

Dari depinisi kemampuan kinestetik yang telah dijelaskan diatas dapat di simpulkan bahawa permainan sepak bola adalah permaianan yang tepat untuk meningkatkan kemampuan kinestetik jasmani anak (kemampuan dalam melakukan gerak tubuh) dengan melakukan permaianan sepak bola anak dapat meningkatakan kemampuan kinestetik jasmani.

Selain itu hasil penelitian Selanjutnya penelitian Rizki (2016), yang berjudul " Mengembangkan Kemampuan Motorik Kasar Melalui Bermain Sepak Bola Pada Anak Kelompok A TK Masyithol-Al-Amin" data yang diperoleh dari siklus I dan siklus II menunjukan bahwa melalui bermain sepak bola dapat meningkatkan kemampuan motorik kasar. Berdasarkan penelitian relapan yang ada peneliti menemukan persamaan yang ada, dalam penelitian ini sama-sama melaui permainan sepak bola namun peneliti sebelumnya meningkatkan kemampuan motorik kasar dan peneliti (penulis) meningkatakan kemampuan kinestetik jasmani.

Sejalan dengan hasil yang telah didapatkan dapat disimpulkan bahwa melalui permaianan sepak bola dapat meningkatkan kemampuan kinesteik jasmani Anak PAUD Segar Jaya Desa Segayam Kecamatan Pemulutan Selatan. 


\section{KESIMPULAN DAN SARAN}

Dapat disimpulkan bahwa permainan sepak bola dapat meningkatkan kemampuan kinestetik jasmani anak. peningkatan tersebut dapat dilihat dari kondisi awal pada tahap pra siklus kemampuan kinestetik jasmani anak kelompok B2 berada pada kriteria belum berkembang dengan persentse 14,3\%. Pada siklus I dengan presentase 42,9\% meningkat menjadi berkembang sesuai harapan, dengan dilakukan pembelajaran dan praktik secara lansung disertai peragaan dari guru sebelum melakukan kegiatan dan perubahan jarak tempuh lapangan menjadi meningkat pada siklus II dengan presentase $85,7 \%$ dengan adanya penambahan peragaan sebelum melakukan praktik secara lansung dilapangan dan perubahan jarak tempuh lapangan menjadi kriteria berkembang sangat baik. Anak sudah mampu meningkatkan kemampuan kinestetik jasmaninya melalui permainan sepak bola.

Melalui permainan sepak bola seperti bermain dengan sikap yang gembira, menangkap bola (penjaga gawang), menendang bola, menggiring bola dan berlari sejauh 5 meter sesuai kecepatan waktu. Hasil penelitian menunjukkan bahwa kemampuan kinestetik jasmani pada anak kelompok B2 (usia 5-6 tahun) di Paud Segar Jaya Desa
Segayam Kecamatan Pemulutan Selatan dapat ditingkatkan melalui permainan sepakbola.

Penelitian ini memberikan saran untuk

1. Bagi Anak

Anak dapat meningkatkan kemampuan kinestetikjasmani anak usia 56 tahun di PAUD Segar Jaya Desa Segayam Kecamatan Pemulutan Selatan melalui permaianan sepak bola

2. Bagi guru

Guru hendaknya menerapkan lebih rutin lagi permaianan diluar ruangan sehingga dapat meningkatakan kemampuan kinestetik jasmanai anak sesuai harapan.

3. Bagi Lembaga Sekolah

Memyediakan berbagai fasilitas untuk melakukan kegiatan permaianan agar dapat digunakan untuk meningkatkan kemampuan kinestetik jasmanai anak.

4. Bagi Peneliti Selanjutnya

Peneliti selanjutnya diharapkan untuk mengembangkan instrumennya yang digunakan untuk mengukur kemampuan kinestetik jasmani agar kemampuan kinestetik jasmani anak dapat meningkat dengan optimal.

\section{DAFTAR PUSTAKA}

Budio, (2012). ). Pengaruh Kemampuan dan Pengalaman Kerja Terhadap Kinerja Pekerja Pelaksanaan Bekisting Pada Pekerjaan Beton. 
Diakses dari Jurnal Rekayasa Sipil. Jurnal Scolar.google.co.id >citations. Pada Tanggal 08 Februari 2019 pada pukul 21:48.

Eci. (2017). Buku Pintar Olahraga dan Permainan Tradisional. Jakarta : Laksana.

Kurniati, Euis. (2016). Permainan Tradisuonal. Jakarta : PT Kharisma Putra Utama.

Madyawati, Lilis. (2017). Strategi Pengembangan Bahasa Pada Anak. Jakarta : PT

Muhajir. (2015). Jasmani Manusia dalam Perpektif Para Ahli Pendidikan. Di akses dari jurnal Qatharun'a. Jurnal.uinbanten.ac.id $>$ article. Pada Tanggal 10 Februari 2019 pada pukul 13:51.

Murtaldo, (2016). Kumpulan Metode Pembelajaran. Bandung : PT Sarana Tutorial Nurani Sejahtra.

Mikanda, (2014). Buku Super Lengkap Olahraga. Jakarta : Dunia Cerdas.

Rochim. 2017. Konsep Pendidikan Jasmani, Akal dan Hati Dalam Perspektif Hamka. Diakses dari jurnal ejournal.kopertais4.or.id>article>vie w.Pada tanggal 12 februari 2019 pada pukul 08:20.

Sudiro Achmad. (2018). Perilaku Organisasi. Jakarta : Bumi Aksara

Suherman. (2017). Pengaruh Kemampuan Membaca Alqur'an Terhadap Hasil Belajar Mahasiswa Politeknik Negri Medan. Diakses dari Jurnal Ansiru Pai. Jurnal.uisui.ac.id > ansiru > view. Pada Tanggal 08 Februari 2019 pada pukul 21:38
Sujiono (2013). Bermain Kreatif Berbasis Kecerdasan Jamak : Jakarta PT Indeks

Umama. (2016). Pojok Bermain. Jogjakarta : Stiletto Book

Witono, (2017). Buku Pintar Sepak Bola. Jakarta: Anugrah

Yuliani Nurani ,dkk. (2013). Konsep Dasar Pendidikan Anak Usia Dini. Jakarta : PT Indeks. 